\title{
Consumers' Attitudes towards Financially Securing Old Age
}

\author{
Iwona Olejnik and Sylwester Bialowas
}

\begin{abstract}
The research problem of this article is identifying the attitudes of consumers towards having retirement financial security and the factors shaping these attitudes. Based on the review of the literature on the attitudes of consumers towards retirement financial security, several factors were identified, which may be deemed key elements in the model of attitudes. These include: consumers' belief in the need/sense of additional saving for old age, knowledge about retirement provisions, the perception of the bodies responsible for retirement provisions, intergenerational transfers within families and retirement aspirations.

The primary data utilised in the study were obtained from representative quantitative studies. The representative quantitative survey was carried out, with a direct survey questionnaire, in 2014 (sample=1163). In the analysis, Exploratory Factor Analysis was used.

The study revealed that the model of the attitudes of Poles towards retirement financial security includes all the aforementioned factors, except for the way of perceiving the bodies responsible for retirement provisions. The results of the study indicate that the constructs selected in the model of attitudes depend strongly on the self-assessment of health and on the age factor.
\end{abstract}

Index Terms - Financial behaviour, old age financial security, attitudes towards finances.

\section{INTRODUCTION}

Nowadays, almost in all developed countries the percentage of individuals who have retired due to their age is rising. Therefore, the last stage of life has become a subject of interest not only of various areas of science but also of social policy and the economy. The occurring changes contribute to the growing financial inefficiency of the state pension provision systems. This, in turn, determines the necessity to make changes in the structure of income received during retirement - decreasing the dominance of the provisions acquired from the state institutions and increasing securing one's old age with private funds. However, it is difficult to precisely determine what share of retirement financial security should be ensured by optional individual saving and other ways of financially securing one's old age. Undoubtedly, too low savings may cause the quality of life in retirement to decline (in the case of obtaining insufficient provisions from the state system). Moreover, economic and social changes, in particular those occurring in the job market, along with society becoming more affluent, economic migration, but also the changes in the family model and legal regulations in the retirement provision systems, contribute to

Manuscript received March 9, 2016; revised July 13, 2016.

The authors are with the Poznan University of Economics and Business, Poland (e-mail: i.olejnik@ue.poznan.pl). the changes in the attitudes and behaviours of consumers in the area of their intertemporal choices.

At the same time, it is anticipated that a substantial number of professionally active people do not, or will not, have accumulated sufficient savings - both provided by the state and built up individually - to secure the retirement stage of their life. Consequently, an important question arises: how should people's needs in this stage of life be financed? Providing retirement financial security may be left to the state institutions or to the individuals - the future pensioners. As a consequence of the demographic, economic and social changes presented above, a rising financial insecurity of the elderly can be observed, who due to their advanced age are no. longer able to work.

In the face of the above problems, in 1999 a pension system reform was launched in Poland. The previously existing defined benefit system was at this time replaced by the three-pillar defined contribution system: the first two elements are compulsory, with the first pillar on the pay-as-you-go basis managed by the state and the second capital-based, with retirement assets managed by private institutions - based on pension fund societies (since 2014, participation in this pillar is optional); and the third element the optional third pillar of the pension system.

As the forecasts for the replacement rate (i.e. the relation between the average amount of a drawn pension and the average (or last) salary) of pensions in Poland obtained from the compulsory part of the pension security system are very pessimistic (the future pensioners will draw about 30 percent of the amount of their last salary), in order to maintain an adequate standard of living of the future pensioners, the significance of additional, voluntary, individually accumulated savings is pointed out [1]. Therefore, identifying consumers' attitudes towards attaining retirement financial security becomes an important issue. The aim of the reflections presented in this article is building a model of consumers' attitudes towards retirement financial security.

\section{LITERATURE OVERVIEW}

The studies of the attitudes and behaviours of consumers towards broadly understood financially securing one's old age (including, apart from saving, inter-generational transfers, reversed mortgage, continuing work after reaching retirement age, etc.) can be found in the world literature [2]-[9]. The necessity to conduct research and build the models of consumers' attitudes and behaviours in relation to retirement financial security is emphasized by, among others: [10]-[13]. As N. Barr [2010, pp. 130] argues: "the economics of pensions systems may lead to false conclusions, since it tends to focus on the financial aspects, such as the analysis of assets 
portfolios," but there is no. knowledge about the consumer, his/her competences, attitudes and behaviours.

The attitudes which are the subject of interest of this article are understood in the literature as conscious processes influencing one's reactions towards the world. An attitude may be defined as "a covert propensity to react or behave in a certain way towards the object of the attitude" [14]. Attitudes consist of three components: cognitive, (e.g. the knowledge of the object of the research, being convinced of the necessity to undertake particular actions; emotional (i.e. the experienced potential emotions towards the research object); and behavioural (e.g. motives for behaviour, planning and undertaking actions). Despite this distinction, single statements used in consumer research often include elements from various components.

The attitude of consumers towards retirement financial security expresses their particular, relatively permanent attitudes towards particular aspects related to their perception and, subsequently, planning actions aimed at providing for their needs in old age. Consumers' attitudes may, but do not have to, influence their behaviours related to ensuring retirement financial security. Similarly, also attitudes may, but do not have to, be influenced by behaviours. While the key factor affecting accumulating additional assets aimed at ensuring retirement financial security is the actual possibility to put aside a part of one's earnings, if a consumer does not save, his/her positive attitude (in the case of the improvement of the household's material situation) may facilitate making such a decision.

When reviewing the literature on consumers' attitudes relating to ensuring one's retirement financial security, certain factors have been identified, which may be the elements of the models of attitudes. These include in particular:

- consumers' belief in the need/sense of saving additionally for old age,

- knowledge about retirement provisions,

- the perception of the bodies responsible for retirement provisions,

- inter-generational transfers within a family,

- retirement aspirations.

\section{A. Beliefs and Knowledge Regarding the Need of Ensuring Oneself Retirement Financial Security}

Consumers' views and beliefs about retirement financial security are connected with their knowledge. The combination of awareness and knowledge (and also skills) is the element of the so-called retirement literacy. Retirement competence, in accordance with the term defined by OECD/INFE (International Network on Financial Education) [15], shapes consumers' attitudes and behaviours which are necessary for making the rational decisions which enable individuals to achieve financial well-being when retired.

An inadequate level of awareness of the necessity to obtain additional retirement financial security may lead to being unable to make rational choices, the inability to predict their consequences, or lacking the competence to evaluate the decisions made and a passive attitude towards the changes occurring in the market. The lack of awareness of the necessity to personally take care of one's retirement security, emphasized by numerous researchers [13], may result in a reduced quality of life in retirement. Consumers, who are unaware of the need to start saving as soon as possible to additionally financially secure their old age, will not look for information and, consequently, they will not use the solutions enabling them to acquire additional retirement provision. What is more, with a prospect of long-term saving to financially secure one's retirement, consumers will often point at other, more urgent needs [16].

The knowledge about retirement financial security makes it possible to set realistic goals of saving for retirement and making rational choices. The problem of an inadequate level of knowledge in this subject can be observed not only in Poland. Studies conducted in various parts of the world indicate that very many consumers lack basic knowledge about retirement financial security. Inadequate is the knowledge related not only to general basics such as the ability to make simple financial calculations [17]-[19], but also to concrete products or services [20]-[22], in particular pension funds [23]-[24].

As indicated by N. Barr [13], not only do very few people understand the general mechanism of the pension system, but what can be observed in this area is almost "innate ignorance". According to the N. Barr, this means that one may demonstrate "refined finance knowledge," but at the same time be an ill-informed consumer with regard to retirement financial security. It is a result of retirement products being too complex and consumers lacking adequate competence to evaluate and compare them [25].

\section{B. Perception of the State Bodies Responsible for Retirement Provisions}

Another area of the researchers' interest in consumers' attitudes towards retirement financial security is the perception of the bodies responsible for retirement provisions. Particularly important here is the consumer's trust in the public pension system [26]-[27]. Trust is a prerequisite for building an effective and reliable pension system. It results from a few factors [28]. Trust decreases the consumers' discomfort in the process of decision-making, because it allows transferring responsibility for these decisions in the areas where they are not competent enough to make the best decisions. At the same time, trust gives a psychological sense of financial security in the far future [29]. On the other hand, as mentioned before, for the governments, trust is a key factor enabling them to run effective pension security policies. Hyde and Dixon point at the conditions that should be a basis for conducting analyses related to trust for the institutions that manage pension assets. These are, among other conditions, organizational transparency, the guarantee of receiving provisions in the future, or financial stability related to the level of the possible replacement rate. These factors should be taken into account in the evaluation of the ability of pension institutions to earn social trust [29].

The analyses regarding trust towards the pension system, as well as trust in the state, in this respect are conducted in many countries worldwide. They frequently relate to the factors which determine the level of trust and the influence of trust on particular decisions related to saving for old age. For example, in a study conducted in the US, Kim, Kwon and Anderson [30], constructed a synthetic measure of consumers' attitudes using 6 questions (rated on a 4-point Likert scale). 
They included: trust in owning a sufficient amount of money to live comfortably when retired, trust that one is financially prepared for retirement, trust in owning sufficient funds to cover medical expenses, trust in owning a sufficient amount of money for day-to-day outgoings, trust that the owned assets will last for a long period of time and trust that the owned savings will not run out until the end of one's life. Such research includes also the role of the 'state' in ensuring retirement financial security. For example, the conclusion of a study conducted on the British market was that in the opinion of every third young individual, pensions should primarily be a domain of the 'state'; however, only $4 \%$ of these individuals believed that their own pension should be financed mainly from this source [31].

\section{Intergenerational Transfers within a Family-Leaving an Inheritance}

An important area of the analysis of consumers' attitudes towards retirement financial security is also intergenerational transfers, particularly the left inheritances [9], [32]-[35].

The motive for saving for retirement with a view to leaving behind an inheritance has a different meaning in different societies. For example, in Japan this motive is insignificant. Also the process of the decumulation of savings is compliant with the classical life cycle model. However, research conducted on the American market has proved that the motive of an inheritance ranks high in the hierarchy of motives for saving (particularly among the highest earners and estate owners). As a consequence, the percentage of the consumers who have received, are expecting to receive, or are planning to leave an inheritance, is lower in Japan than in the US. However, the ratio of the value of inheritances to households' wealth in both countries is comparable. This results from the higher value of Japanese inheritances [7], [36].

\section{Retirement Aspirations}

The attitudes of consumers towards retirement financial security are also shaped by their expectations of life after retiring [37]-[40]. A number of authors point out that individual retirement aspirations are of major importance in predicting people's retirement choices, including the decision on the moment of retiring, but also the decision to save for retirement [41]-[44].

The anticipated lifestyle when retired may evoke mixed feelings in workers. They may be both negative (limited contact with other people, lower income, loss of power, etc.) and positive (opening up for new social challenges, developing new interests). According to the research conducted by Lim [45], generally, workers do not perceive retiring negatively, they just fear some aspects of this process Research conducted to date in many countries also indicates that individuals whose attitude towards life in retirement is positive are also more likely to finish their professional career sooner [46]-[47].

Retirement aspirations are also a result of, among other factors, the sense of being in control over the process of adjusting to retiring. Taylor and Shore [47] point to such factors connected with retirement aspirations as the predicted reactions of other people to the fact that one is giving up working, or the attitudes towards free time mentioned above [42], [48].
What has a considerable importance in the process of shaping the attitudes of consumers towards retirement financial security is also a subjective estimation of one's own life expectancy. The differences in the anticipated life expectancy lead to various attitudes and behaviours of consumers in relation to the retirement financial security. If people subjectively expect that they will live longer than their objective life expectancy (estimated on the basis of statistical data on mortality in particular age groups), then, according to the life cycle hypothesis, they should limit their current consumption spending in favour of saving [49]-[50].

\section{RESULTS-CONSUMERS' ATTITUDES TOWARDS RETIREMENT FINANCIAL SECURITY}

In order to construct a model of attitudes towards retirement financial security, the initial step included extracting the elements that build up these attitudes in the following areas: cognitive, emotional and behavioural. As the basis for the research conducted by ourselves, 23 statements were extracted. The cognitive component included the beliefs about the features of the evaluated object and its role and meaning in achieving goals. In this context, the attitudes of consumers were verified towards, among other issues, the trust in the state institutions regarding retirement financial security, the belief in the necessity to save up additionally for old age, the self-assessment of one's level of knowledge about the pension system and the self- perception as a financially responsible person.

The emotional elements included the positive or negative emotions of the consumers experienced in relation to additional saving in order to financially secure one's old age. The example statements used to measure this component are: "I am afraid that the assets I have accumulated for my old age will run out too soon." "I envy those people who save additionally (or more than me) for retirement," "Saving for retirement makes me feel secure" or "I don't like thinking about financially securing my retirement".

In relation to the behavioural component of a person's attitude, statements are connected with actions (decisions) made to ensure one's old age financial security. Among them, such statements were found: "I am planning my retirement financial future," I often talk to my family about my financial security when I retire," "I know exactly how high my capital accumulated in ZUS (and/or OFE) is," "I save to provide financial security to my family".

In order to narrow down the amount of information included in numerous variables diagnosing the attitudes towards retirement financial security to a small number of explanatory measures, Principal Components Analysis (PCA) was used. The justification for choosing the PCA was primarily the intention to explore the structure of the obtained data set and the use of non-correlated principal components in the further multi-dimensional analyses.

From the initial set of 23 statements, tested with a 5-point Likert scale, 10 variables (statements) were removed as a result of a series of analyses eliminating the positions characterised by a considerable shortage of data, poor common variation and 'loading' of more than one factor. The eliminated statements concerned the role of the state in providing retirement financial security, i.e. "I trust that the 
state will not leave the retirees to themselves and will provide me with a decent pension.," "I would like the state to deduct enough money from my incomes so that I don't have to save additionally for retirement.," the possibilities to manage one's retirement savings: "In case of an urgent need it should be possible to withdraw the accumulated retirement savings," as well as the aspects related to the emotions connected with retirement financial security 'I feel guilty that I haven't started saving yet (or I'm saving too little) for additional pension.," "I don't like thinking about financially securing my retirement," "I envy those people who save up additionally (or more than me) for retirement.," "I'm afraid that the assets I have accumulated for my old age will run out too soon.". Three statements have been removed from the behavioural area of attitudes: "I'd like to know, how much I must save additionally to lead a decent life when I retire," "I'm planning my financial future in retirement." and "If I earned more, I would save additionally (or more) for retirement."

The evaluation of the adequacy of the data used for factor analysis conducted with the Kaiser-Meyer-Olkin test (measure of sampling adequacy - KMO) on the level 0.757 and with the Bartlett sphericity test, which was 1318.805 with 78 degrees of freedom and value $p=0,000$, allows using the/this factor model in (the) further research.

The subsequent step included extracting the factors by means of Principal Component Analysis. As a result, ultimately four factors were obtained, built in total from 13 variables (common variation from 0.421 to 0.830 ), selected on the basis of the Kaiser criterion (suggesting solutions based on this number of factors), and verified additionally with the Cattel scree criterion. The rotation of factors was conducted with the use of the VARIMAX orthogonal rotation with the Kaiser normalization. Table I presents the dependence between input variables (statements) and member variables.

As a result of the conducted research process, a model of consumers' attitudes towards retirement financial security was obtained. 4 factors were extracted, explaining $57 \%$ of the total variance. These include:

1. consumers' belief in the need/sense of additional saving for old age,

2. knowledge about retirement provisions,

3. securing one's family (inheritance),

4. retirement aspirations.

TABLE I: RESUlTS OF THE ANALYSIS OF PRINCIPAL COMPONENTS (STRUCTURE MATRIX)

\begin{tabular}{|c|c|c|c|c|}
\hline \multirow[t]{2}{*}{ Statements: } & \multicolumn{4}{|c|}{$\begin{array}{l}\text { Components (values of factor } \\
\text { loadings) }\end{array}$} \\
\hline & 1 & 2 & 3 & 4 \\
\hline $\begin{array}{l}\text { Saving for retirement makes me feel } \\
\text { secure }\end{array}$ & $0,745^{*}$ & & & \\
\hline $\begin{array}{l}\text { I save to ensure myself an adequate } \\
\text { quality of life when I retire }\end{array}$ & 0,715 & & & \\
\hline Saving for retirement makes sense & 0,597 & & & \\
\hline $\begin{array}{l}\text { You should start saving for } \\
\text { retirement as soon as possible }\end{array}$ & 0,524 & & & \\
\hline $\begin{array}{l}\text { I know much about the pensions } \\
\text { system in Poland }\end{array}$ & & 0,830 & & \\
\hline $\begin{array}{l}\text { I like reading articles and watching } \\
\text { programmes about saving for }\end{array}$ & & 0,720 & & \\
\hline
\end{tabular}

\section{retirement}

I know exactly how high my capital accumulated in ZUS (OFE) is

0,580

I often talk to my family about my

financial security when I retire

0,504

I would prefer to live modestly when

I retire, just to be able to leave an

inheritance

I would like to accumulate enough

savings for retirement to be enough

for an inheritance for my family

I save to leave behind financial

security for my family

I often imagine my life in retirement

I will live longer than other people

born in the same year as me

Source: own calculations
0,790

0,696

0,680

0,822
The first of the extracted factors - belief in the need/sense of additional saving for old age, is connected with the conviction that it is important and necessary to start saving for old age as early as possible. This dimension is connected with the motive of security and ensuring oneself an adequate quality of life in retirement. This factor explains $26 \%$ of the total variance.

Also the second extracted factor, knowledge about retirement provisions, is characterised by a high value of factor loadings (it explains $12 \%$ of the total variance). This factor describes the actions of consumers in the behavioural aspect relating to acquiring information about retirement financial security and self-assessment of one's knowledge.

In the case of third factor, it can be observed that it is characterised by a clear focus on the aspects related to financial securing one's family and the wish to leave an inheritance (it explains $11 \%$ of total variance). The last of the factors takes into account the time perspective of consumers' behaviour and it was named "retirement aspirations". It accounts for $8 \%$ of the total variance and it is characterized by a high value of factor loadings for the elements related to planning life in retirement. They concern the anticipated life expectancy and the vision of one's life in retirement.

\section{DETERMINANTS OF CONSUMERS' ATITUDES TOWARDS FINANCIAL SECURITY IN OLD AGE}

In the subsequent stage of the research, an analysis was conducted addressing the influence of various features of consumers on their attitudes towards securing their old age, expressed by the constructs acquired in the model presented above.

The dependence between the features of consumers and attitudes towards retirement financial security was identified with the use of the Pearson correlation coefficient. The relationship between the models of attitudes towards retirement security and consumers' features is presented in Table II.

TABLE II: COMPONENTS OF THE MODEL OF ATTITUDES TOWARDS RETIREMENT FINANCIAL SECURITY VERSUS CONSUMERS' FEATURES (PEARSON CORRELATION COEFFICIENT)

\begin{tabular}{llll}
\hline & & & Securing \\
Attitudes & Beliefs & Knowledge & Family \\
Variables & & Financially & \\
\hline
\end{tabular}




\begin{tabular}{|c|c|c|c|c|}
\hline Age & $0.301 * *$ & 0.035 & $-0.125^{* *}$ & $0.469 * *$ \\
\hline Education & -0.004 & $0.118 * *$ & 0.076 & $-0.204 * *$ \\
\hline $\begin{array}{l}\text { Number of } \\
\text { people in } \\
\text { household }\end{array}$ & $-0.185 * *$ & -0.042 & $0.196^{* *}$ & -0.083 \\
\hline $\begin{array}{l}\text { Income per capita } \\
\text { in household }\end{array}$ & $0.141 * *$ & $0.103^{*}$ & -0.013 & -0.073 \\
\hline $\begin{array}{l}\text { 'Good' age to } \\
\text { start saving } \\
\text { additionally for } \\
\text { retirement }\end{array}$ & $-0.185^{* *}$ & 0.002 & 0.071 & 0.033 \\
\hline $\begin{array}{l}\text { The amount of } \\
\text { savings needed to } \\
\text { accumulate to } \\
\text { maintain the } \\
\text { current quality of } \\
\text { life when retired }\end{array}$ & $0.134 * *$ & 0.033 & 0.030 & -0.057 \\
\hline $\begin{array}{l}\text { Preferred age of } \\
\text { ending one's } \\
\text { career }\end{array}$ & 0.007 & $0.169 * *$ & 0.015 & $0.104 *$ \\
\hline $\begin{array}{l}\text { Health self - } \\
\text { assessment }\end{array}$ & $-0.144 * *$ & $0.109^{*}$ & $0.161^{* *}$ & $-0.175^{* *}$ \\
\hline $\begin{array}{l}\text { Assessment of } \\
\text { relations with } \\
\text { children }\end{array}$ & $0.137 * *$ & 0.048 & $0.220 * *$ & -0.005 \\
\hline $\begin{array}{l}\text { Level of } \\
\text { optimism }\end{array}$ & 0.063 & $0.093^{*}$ & $0.090 *$ & $-0.101^{*}$ \\
\hline $\begin{array}{l}\text { Level of finance } \\
\text { risk acceptance }\end{array}$ & -0.051 & $0.165^{* *}$ & 0.001 & $-0.153^{* *}$ \\
\hline
\end{tabular}

The age of the head of the household is a determinant which is strongly connected with the selected factors. The attitudes towards retirement financial security in terms of the belief in the necessity to save more, as well as retirement aspirations, become more positive with a consumer's age. Slightly surprising is the negative correlation of the age variable with the attitudes towards financially securing one's family. This may result from the choice of the indicators used when identifying this factor, clearly directed at the financial aspects of securing one's family. No. correlation was found between the age and the 'knowledge' factor. In the case of the next feature of the head of household - education - only two statistically significant relationships were noted within the selected factors. This variable correlates with knowledge (positive correlation) and retirement aspirations (negative correlation).

Another determinant influencing the attitudes towards retirement financial security is the number of people in the household. The increase in the number of people in the household is positively correlated with the attitudes towards financially securing one's family, but negatively with the belief in the sense of saving for old age. This important conclusion confirms the significant role of family members (children) in providing retirement financial security. The representatives of a substantial number of households barely notice the need to save additionally for retirement (most probably expecting support from their adult children), which may be confirmed by their positive attitudes towards financially securing the family.

The analysis of the correlations between the attitudes towards retirement financial security and average household income per capita indicates a positive correlation, particularly in the case of the belief in the necessity to save additionally for retirement. A statistically significant relationship was also noted for the 'knowledge' factor - together with the increase in income per capita, rises the level of activity in looking for information about retirement security.

The research on the correlation between attitudes towards retirement financial security and psycho-social features was also conducted. Health self-assessment, the relations with children, the level of optimism and the attitude towards risk were all taken into consideration (in each case, a 5-point scale was used).

Similarly to the demographic-economic features, the correlations between the variables are not very strong. The most statistically significant correlations with the attitudes were observed in the health self-assessment - the increase in the satisfaction from it is accompanied by a higher level of knowledge about retirement financial security and more positive attitudes towards financially securing one's family. At the same time, the belief in the necessity to save additionally, as well as retirement aspirations decrease. It is the strongest in the whole analysed group, but also expected correlation occurs between the assessment of relations with children and the attitudes towards financially securing the family. The assessment of the relations with children also affects the belief in the necessity to save for retirement.

The level of optimism and the attitude towards taking financial risk positively correlate with the attitudes towards knowledge about retirement security and negatively with the retirement aspirations. In both cases the correlations are relatively weak, but were slightly higher for the level of risk acceptance.

Moreover, it turned out that the lower the age indicated by a consumer in which it is necessary to start saving additionally for retirement and the higher amount indicated to be earmarked for this aim - the higher the belief in the necessity to save for retirement. The perceived right age for starting saving for retirement and the indicated amount of savings making it possible to maintain a desired quality of life in retirement, do not correlate with the three remaining components of attitudes. A low, but statistically significant positive relationship was noted between the indicated age when a consumer would like to end his/her professional career and the factor 'knowledge' and retirement aspirations.

\section{CONCLUSION}

The use of exploratory factor analysis allowed building a model of consumers' attitudes, in which four constructs were selected: the belief in the necessity to secure oneself with additional retirement provisions, knowledge, securing financially one's family, (i.e. intergenerational transfers) and retirement aspirations. The model did not include consumers' attitudes towards the role of the state in ensuring retirement financial security.

The results of the study indicate that the constructs selected in the model of attitudes depend on a number of variables characterising the consumers. The greatest number of statistically significant relationships between the selected attitudes was noted for the self-assessment of health and the strongest relationships - for the age factor. Research [51], [52] 
proves that a significant predictor of attitudes and behaviours of consumers towards retirement financial security is the condition of their health. The authors prove that the better someone's health, the more positive their attitude towards retirement and the more probable it is that they will accumulate additional savings for this period of life.

An important determinant of consumers' attitudes and behaviours towards retirement financial security is age. The older a person, the more frequently they think about saving and make decisions concerning this, including saving for retirement. As early as in the late 1940s, R. Harrod [53] described the so-called 'hump saving', hypothesizing that savings would be highest in the middle years of a person's life. However, as D. Grace, S. Weaven and M. Ross [54] point out people very often start making plans for retirement financial security only just before retiring, which makes it impossible to accumulate satisfactory retirement capital. The research conducted by C. Rickwood and L. White [11] reveals that the last moment for starting saving additionally for retirement is the age of 40. At a younger age, retirement seems to be a too distant period of life to save for. Age also influences the attitudes towards those bodies that are responsible for retirement provisions [31].

\section{REFERENCES}

[1] I. Olejnik, "Retirement savings-determinants of households' behaviour," International Journal of Social Sciences, vol. II , no. 3, pp. 105-116, 2013.

[2] P. J. Bayer, B. D. Bernheim, and J. K. Scholz, "The effects of financial education in the workplace: Evidence from a survey of employers," National Bureau of Economic Research Working Paper Series, Working Paper No. 565, 2008.

[3] A. Börsch-Supan, A. Reil-Held, and D. Schunk, "Saving incentives, old-age provision and displacement effects: Evidence from the recent German pension reform," Journal of Pension Economics and Finance, vol. 7, pp. 295-319, 2008.

[4] Y. Chen and J. Scott, "Phase retirement: Who opts for it and towards what end?" European Papers on the New Welfare, vol. 6, pp. 16-130, 2006.

[5] O. Gough and R. Hick, "Ethnic minorities, retirement planning and Personal Accounts," International Journal of Sociology and Social Policy, vol. 29, no. 9/10, pp. 488-497, 2009.

[6] T. K. Hira, W. L Rock, and C. Loibl, "Determinants of retirement planning behaviour and differences by age," International Journal of Consumer Studies, vol. 33, pp. 293-301, 2009.

[7] C. Y. Horioka, K. Yamashita, M. Nishikawa, and S. Iwamoto. (2003). The impact of bequest motives on the saving behavior of the aged in Japan. [Online]. Available: http://www.rand.org/content/dam/rand/www/external/labour/seminars /adp/pdfs/adp_horioka.pdf

[8] A. A. Lusardi, "Household saving behavior. The role of financial literacy, information and financial education programs," National Bureau of Economic Research Working Paper Series, Working Paper 13824, 2008.

[9] T. Piketty, Capital in the Twenty-First Century, Cambridge, MA: Belknap Press, 2014.

[10] A. Lusardi, Planning and Saving for Retirement, Department of Economics, Hanover, NH: Dartmouth College, 2003.

[11] C. Rickwood and L. White, "Pre-purchase decision-making for a complex service: retirement planning," Journal of Services Marketing, vol. 23, no. 3, pp. 145-153, 2009.

[12] S. Singh and N. Kumar, "A review on pension system," International Journal of Advanced Research in Management and Social Sciences, vol. 3, no. 12, 2014.

[13] N. Barr, Economics of the Welfare State, Oxford University Press, Oxford, 2012.

[14] D. F. Alvin and J. Scott, "Attitude change: Its measurement and interpretation using longitudinal surveys," Understanding Change in Social Attitudes, Dartmouth, 1996.

[15] A. Atkinson and F. Messy, "Measuring financial literacy: Results of the OECD / International Network on Financial Education (INFE) pilot study," OECD Working Papers on Finance, Insurance and Private Pensions, no. 15, OECD Publishing, 2012.

[16] E. Clery, S. McKay, M. Phillips, and C. Robinson, "Attitudes to pensions: The 2006 survey," DWP Research Report No. 434, HSMO, Norwich, 2007.

[17] D. Bernheim, "Financial illiteracy, education and retirement saving," Living with Defined Contribution Pensions, Philadelphia: University of Pennsylvania Press, 1998.

[18] D. Moore, "Survey of financial literacy in Washington State: Knowledge, behavior, attitudes and experiences," Technical Report 03-39, Social and Economic Sciences Research Center, Washington State University, 2003.

[19] T. Jappelli, Health Risk and Portfolio Choice, Working Paper, University of Salerno, 2005.

[20] S. Benartzi and R. H. Thaler, "Naive diversification strategies in defined contribution savings plans," American Economic Review, vol. 91, no. 1, pp. 79-98, 2001.

[21] J. J. Choi, D. Laibson, and B. C. Madrian, "Are empowerment and education enough? Underdiversification in 401 (k) plans," Brookings Papers on Economic Activity, vol. 36, no. 2, pp. 151-198, 2005.

[22] A. Lusardi A. and O. S. Mitchell, "Financial literacy and retirement preparedness: Evidence and implications for financial education," Business Economics, vol. 42, no. 1, pp. 35-44, 2007.

[23] D. Miles, The UK Mortgage Market: Taking a Longer-Term View, UK Treasury, 2004.

[24] S. Bialowas, "Saving behavior of the polish households," Zachowania oszczędnościowe polskich gospodarstw domowych, Poznań, Uniwersytet Ekonomiczny w Poznaniu, 2013.

[25] S. Białowąs and I. Olejnik, "Pension literacy and consumers' decisions in the context of pension system reforms," Problems in Social Policy, vol. 29, no. 2, pp. 13-33, 2015.

[26] P. Fronstin, "Retirement patterns and employee benefits: Do benefits matter?" The Gerontologist, vol. 39, no. 1, pp. 37-47, 1999.

[27] C. J. Ruhm, "Why older Americans stop working," The Gerontological Society of America, vol. 29, pp. 294-299, 1989.

[28] P. Taylor-Gooby, "Markets and motives: Trust and egoism in welfare markets," Journal of Social Policy, vol. 28, no. 1, pp. 97-114, 1999.

[29] M. Hyde and J. Dixon, "Can private pensions be trusted? A cross-national review," International Journal of Social Economics, vol. 37, no. 4, pp. 276-292, 2010.

[30] J. Kim, J. Kwon, and E. A. Anderson, "Factors related to retirement confidence: Retirement preparation and workplace financial education," Financial Counseling and Planning, vol. 16, no. 2, pp. 77-90, 2005.

[31] W. Tto, P. White, and C. Duncan, “"Thatcher's children', pensions and retirement. Some survey evidence," Personnel Review, vol. 30, no. 4, pp. 386-403, 2001.

[32] W. G. Gale and J. K. Scholz, "Intergenerational Transfers and the Accumulation of Wealth," Journal of Economic Perspectives, vol. 8, no. 4, pp. 145-160, 1994.

[33] J. Laitner and T. F. Juster, "New evidence on altruism: A study of TIAA-CREF retirees," American Economic Review, vol. 86, no. 4, pp. 893-908, 1996.

[34] F. Modigliani, "The role of intergenerational transfers and life-cycle saving in the accumulation of wealth," Journal of Economic Perspectives, vol. 2, no. 2, pp. 15-40, 1988.

[35] L. J. Kotlifoff and L. H. Summers, "The role of intergenerational transfers in aggregate capital accumulation," Journal of Political Economy, vol. 89, no. 4, pp. 706-732, 1981.

[36] C. Y. Horioka. (2014). Are Americans and Indians more altruistic than the Japanese and Chinese? Evidence from a new international survey of bequest plans. Discussion Paper No. 901. The Institute of Social and Economic Research, Osaka University. [Online]. Available: http://www.iser.osaka-u.ac.jp/library/dp/2014/DP0901.pdf

[37] M. A. Taylor, K. S. Shultz, P. E Spiegel, R. F. Morrison, and J Greene, "Occupational attachment and met expectations as predictors of retirement adjustment of naval officers," Journal of Applied Social Psychology, vol. 37, no. 8, pp. 1697-725, 2007.

[38] A. Crego, A. De La Hera, and D. Martinez-Inigo, "The transition process to post-working life and its psychosocial outcomes," Career Development International, vol. 13, no. 2, pp. 186-204, 2008.

[39] S. Zappala, M. Depolo, F Fraccaroli, D. Duglielimi, and G. Sarchielli, "Postponing job retirement? Psychosocial influences on the preferences for early or late retirement," Career Development International, vol. 13, no. 2, pp. 150-67, 2008.

[40] J. Y. Wong and J. K Earl, "Towards an integrated model of individual, psychosocial and organizational predictors of retirement adjustment," Journal of Vocational Behavior, vol. 75, no. 1, pp. 1-13, 2009.

[41] K. Henkens, "Retirement intentions and spousal support: a multi-actor approach," The Journals of Gerontology: Series B, vol. 54, no. 2, pp. 63-73, 1999. 
[42] T. Beehr, S Glazer, N. Nielson, and S. Farmer, "Work and non-work predictors of employees' retirement ages," Journal of Vocational Behavior, vol. 57, no. 2, pp. 206-225, 2000.

[43] S. Kim and D. C. Feldman, "Working in retirement: the antecedents of bridge employment and its consequences for quality of life in retirement," Academy of Management Journal, vol. 43, no. 6, pp. 1195-210, 2000.

[44] J. A. Schmidt and K. Lee, "Voluntary retirement and organizational turnover intentions: the differential associations with work and non-work commitment constructs," Journal of Business Psychology, vol. 22 , no. 4 , pp. 297-309, 2008

[45] V. Lim, “An empirical study of older workers' attitudes towards the retirement experience," Employee Relations, vol. 25, no. 4/5, pp. 330-47, 2003.

[46] T. L. Gall and D. R. Evans, "Pre-retirement expectations and the quality of life of male retirees in later retirement," Canadian Journal of Behavioural Science, vol. 32, no. 3, pp. 187-97, 2000.

[47] M. Taylor and L. Shore, "Predictors of planned retirement age: An application of Beehr's model," Psychology and Aging, vol. 10, no. 1, pp. 76-83, 1995.

[48] M. Hwalek, I. Fireston, and W. Hoffman, "The role social pressures play in early retirement propensities," Journal of Gerontology, vol. 34 pp. 254-63, 1982.

[49] M. De Nardi, E. French, and J. B. Jones, "Life expectancy and old age savings," American Economic Review: Papers \& Proceedings, vol. 99, no. 2, pp. 110-115, 2009.

[50] T. Bucher-Koenen and S. Kluth. (2013). Subjective Life Expectancy and Private Pensions, [Online], Leibniz Information Centre for Economics, Available: http://hdl.handle.net/10419/79806.

[51] R. C. Atchley and J. L. Robinson, "Attitudes toward retirement and distance from the event," Research on Aging, vol. 4, pp. 299-313, 1982.
[52] R. A. Beehr, "The process of retirement: A review and recommendations future investigation," Personnel Psychology, vol. 39, pp. 31-55, 1986.

[53] J. Perek-Białas and M. Rószkiewicz, Households' Savings for the Old Age, Skłonność gospodarstw domowych do oszczędzania $w$ celu zabezpieczenia okresu starości, Pont Info, Warszawa 1999.

[54] D. Grace, S. Weaven, and M. Ross, "Consumer retirement planning: an exploratory study of gender differences," Qualitative Market Research: An International Journal, vol. 13, no. 2, pp. 174-188, 2010.

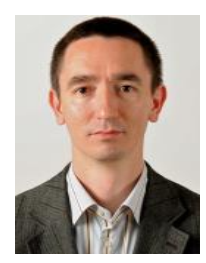

Sylwester Bialowas graduated from the Poznan University of Economics, where he also obtained his $\mathrm{PhD}$ and habilitation. His main scientific areas of interest are financial behaviour and quantitative market research.

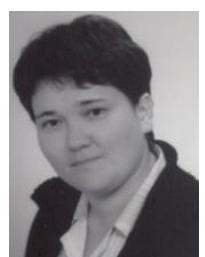

Iwona Olejnik graduated from the Poznan University of Economics (Poland), where she also obtained her PhD. Her main area of interest is consumer behaviour and qualitative market research. She works at the Poznan University of Economics and is the author of about 70 articles. 